\title{
Remittances and COVID-19: A Tale of Two Countries
}

\section{Federico S. Mandelman}

Federal Reserve Bank of Atlanta

\section{Diego Vilán}

Federal Reserve Board

\section{CENTER FOR QUANTITATIVE ECONOMIC RESEARCH}

\author{
CENTER FOR HUMAN \\ CAPITAL STUDIES
}

CENTER FOR FINANCIAL INNOVATION AND STABILITY

CENTER FOR HOUSING AND POLICY

\section{Summary:}

Looking at the effects of the COVID-19 pandemic on workers' remittances flowing from the United States, this article focuses on the experiences of two countries, El Salvador and Mexico, which account for approximately 30 percent of all immigrants currently residing in the United States. Following the second quarter's economic lockdown, transfers to these countries experienced perplexing dynamics. Specifically, remittances to El Salvador witnessed a record 40 percent sudden drop, while Mexico recorded an unexpected 35 percent increase. We discuss some of the narratives proposed to explain this puzzling evidence and propose some alternative hypotheses.

\section{Key findings:}

1. During the COVID-19 lockdown remittances to El Salvador registered a record fall. Conversely, Mexico witnessed a record increase in these transfers

2. The historical evidence does not appear to support the hypothesis that the sharp depreciation of the Mexican peso, in contrast with the fully dollarized Salvadoran economy, explains these results.

3. The ongoing U.S. housing boom and the uncertainty regarding the refugee status of Salvadoran workers may help to explain some of this evidence.

Center affiliation: Center for Quantitative Economic Research and the Americas Center

JEL classification: F40, F41, 010

Key words: Remittances, COVID-19

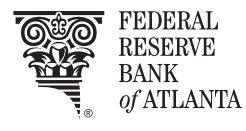

The Federal Reserve Bank of Atlanta's Policy Hub

leverages the expertise of Atlanta Fed economists and researchers to address issues of broad policy interest. Our research centers coordinate this work and seek to influence policy discussions. Areas of interest include: forecasting, fiscal policy, and macroeconomics (Center for Quantitative Economic Research); financial stability, innovation, and regulation (Center for Financial Innovation and Stability); human capital, labor markets, health, and education (Center for Human Capital Studies); and government-sponsored entity reform, mortgage markets, and affordable housing (Center for Housing and Policy). Sign up for email updates at frbatlanta. org/research/publications/policy-hub. 


\section{Remittances and COVID-19: A Tale of Two Countries}

Summary: Looking at the effects of the COVID-19 pandemic on workers' remittances flowing from the United States, this article focuses on the experiences of two countries, El Salvador and Mexico, which account for approximately 30 percent of all immigrants currently residing in the United States. Following the second quarter's economic lockdown, transfers to these countries experienced perplexing dynamics. Specifically, remittances to El Salvador witnessed a record 40 percent sudden drop, while Mexico recorded an unexpected 35 percent increase. We discuss some of the narratives proposed to explain this puzzling evidence and propose some alternative hypotheses.

\section{About the Authors:}

Federico S. Mandelman is a research economist and policy adviser at the Federal Reserve Bank of Atlanta and adjunct professor at Emory University.

Diego Vilán is senior economist at the Federal Reserve Board of Governors and an adjunct professor at John Hopkins University and Georgetown University.

Acknowledgments: The authors thank Nikolay Gospodinov, Tom Heintjes, and Matthias Paustian for helpful comments. The views expressed here are the authors' and not necessarily those of the Federal Reserve Bank of Atlanta or the Federal Reserve System. Any remaining errors are the author's responsibility. This article will be reprinted in FEDS Notes, published by the Federal Reserve Board.

Comments to the author are welcome at federico.mandelman@atl.frb.org or diego.vilan@frb.gov. 


\section{Introduction}

The share of labor earnings that migrants send home to support their families is known as migrant or worker's remittances. These transfers have been growing rapidly in the past few decades and are often used to cover living expenses, supplement food consumption, and afford healthcare and education. Studies have shown that remittances play a critical role in alleviating poverty in middle- to low-income countries. $^{1}$

In recent decades, remittances have become larger and more stable sources of income than traditional external revenue streams such as foreign direct investment, tourism, portfolio equity, and commodity exports. Nowadays, remittances represent the largest source of foreign currency for many developing countries. ${ }^{2}$

Mexico and El Salvador are countries with large communities living and working in the United States, and those communities have traditionally sent large flows of remittances back home. About 11.2 million Mexican-born immigrants reside in the United States, which represents about 9 percent of Mexico's total population. In addition, there are about 25.5 million U.S.-born Hispanics of Mexican origin. ${ }^{3}$ When measured in current U.S. dollars, remittances total about $\$ 40$ billion, approximately equal to 4 percent of Mexico's gross domestic product (GDP). ${ }^{4}$ Remittances in Mexico largely exceed the combined value of oil and tourism as a source of foreign currency. Though sizable, these numbers pale in comparison with the economic significance that migration and remittances have for El Salvador, where remittances stand at $\$ 4.5$ billion, or 21 percent of El Salvador's current GDP. ${ }^{5} \mathrm{~A}$ large migrant population is behind these transfers: 1.3 million Salvadorans reside in the United States, representing 20 percent of El Salvador's total population. In addition, there are 1 million U.S.-born Hispanics of Salvadoran origin. ${ }^{6}$

\footnotetext{
${ }^{1}$ For a detailed survey of the economic impact of remittances on developing countries see Richard Adams, 2011. "Evaluating the Economic Impact of International Remittances On Developing Countries Using Household Surveys: A Literature Review," Journal of Development Studies, Taylor \& Francis Journals, vol. 47(6), pages 809-82. ${ }^{2}$ See updated estimates at https://www.imf.org/external/pubs/ft/fandd/2020/06/COVID19-pandemic-impact-onremittance-flows-sayeh.htm.

${ }^{3}$ https://www.pewresearch.org/hispanic/fact-sheet/u-s-hispanics-facts-on-mexican-origin-latinos/ ${ }^{4}$ https://www.banxico.org.mx/Sielnternet/consultarDirectoriolnternetAction.do?accion=consultarCuadro\&idCuadr $\mathrm{o}=$ CE81\&locale $=\mathrm{es}$

${ }^{5}$ For more information refer to https://www.bcr.gob.sv/bcrsite/?cdr=85.

${ }^{6}$ See https://www.pewresearch.org/hispanic/fact-sheet/u-s-hispanics-facts-on-salvadoran-origin-latinos/ for more details.
} 
In this article, we will show that although the COVID-19 pandemic has had a profound impact on the capacity of these communities to transfer resources back to their relatives and friends back home, it has done so in remarkably different ways. This results are particularly notable when considering that migrants from Mexico and El Salvador share similar demographics, educational backgrounds, and employment situations. ${ }^{7}$

\section{The Impact of COVID-19 on Global Remittances}

On a global scale, the economic crisis wrought by the COVID-19 pandemic has so far been deep and widespread and has greatly affected the capacity of migrant workers to sustain the level of remittances they regularly transfer to their home nations. The World Bank predicts the largest drop in remittances in recent history, with flows expecting to decline by 20 percent from 2019 levels. ${ }^{8}$ The United Nations, together with other multinational organizations, has issued a call to actions to keep remittances flowing by declaring remittance services as essential. ${ }^{9}$

In the United States, the broad economic shutdown in the second quarter of 2020 resulted in a steep 32 percent (annualized) estimated drop in GDP. Furthermore, many of the industries that suffered the brunt of the shutdown were those that typically employ a larger share of migrant workers from the two countries considered here. Restaurant and hotels were at the center of the shutdown, while construction was completely halted in several states. In addition, as workers in the United States switched to home office settings, they refrained from hiring child-care and cleaning services to practice social distancing.

In response to the pandemic, the U.S. government passed the Coronavirus Aid, Relief, and Economic Security Act, known as the CARES Act, which consisted of a stimulus bill amounting to about a tenth of U.S. GDP. This federal government program was not only unprecedented in size but also widespread in nature, including a universal one-time cash payment, expansion of unemployment benefits both in amount and eligibility criteria, and support to small businesses (most notably, the Paycheck Protection Program). The CARES Act was successful in sustaining household consumption amid a sharp decrease in disposable income. However, many migrant workers from both Mexico and El

\footnotetext{
${ }^{7}$ See, for example, https://www.migrationpolicy.org/sites/default/files/publications/RAD-EISalvador.pdf.

${ }^{8}$ See the World Bank's migration and development brief at http://documents.worldbank.org/curated/en/989721587512418006/pdf/COVID-19-Crisis-Through-a-MigrationLens.pdf.

${ }^{9}$ See further information at https://www.knomad.org/covid-19-remittances-call-to-action/.
} 
Salvador do not qualify for any type of government aid or transfer and therefore had to face the full brunt of the pandemic in isolation.

\section{Puzzling Dynamics}

At the onset of the lockdown, private-sector forecasters provided some somber predictions, given the vulnerable situation these migrants were facing. In April, BBVA Research predicted a 17 percent annual drop in remittances to Mexico this year, with a only a very gradual recovery and a return to 2019 levels by $2023-28 .{ }^{10}$ This prediction was particularly pessimistic when considering that remittances to Mexico were growing 6 percent on average over the past decade on annual basis. (Throughout this article, we express numbers in nominal U.S. dollars.)

Against this backdrop, the remittance numbers that emerged after the initial lockdown revealed an interesting puzzle: while flows to El Salvador dropped by 40 percent with respect to the previous year-in line with the practitioners' predictions-remittances flowing from the United States to Mexico increased by 35 percent in March (see figure 1).

\section{Figure 1: Remittances to El Salvador and Mexico}

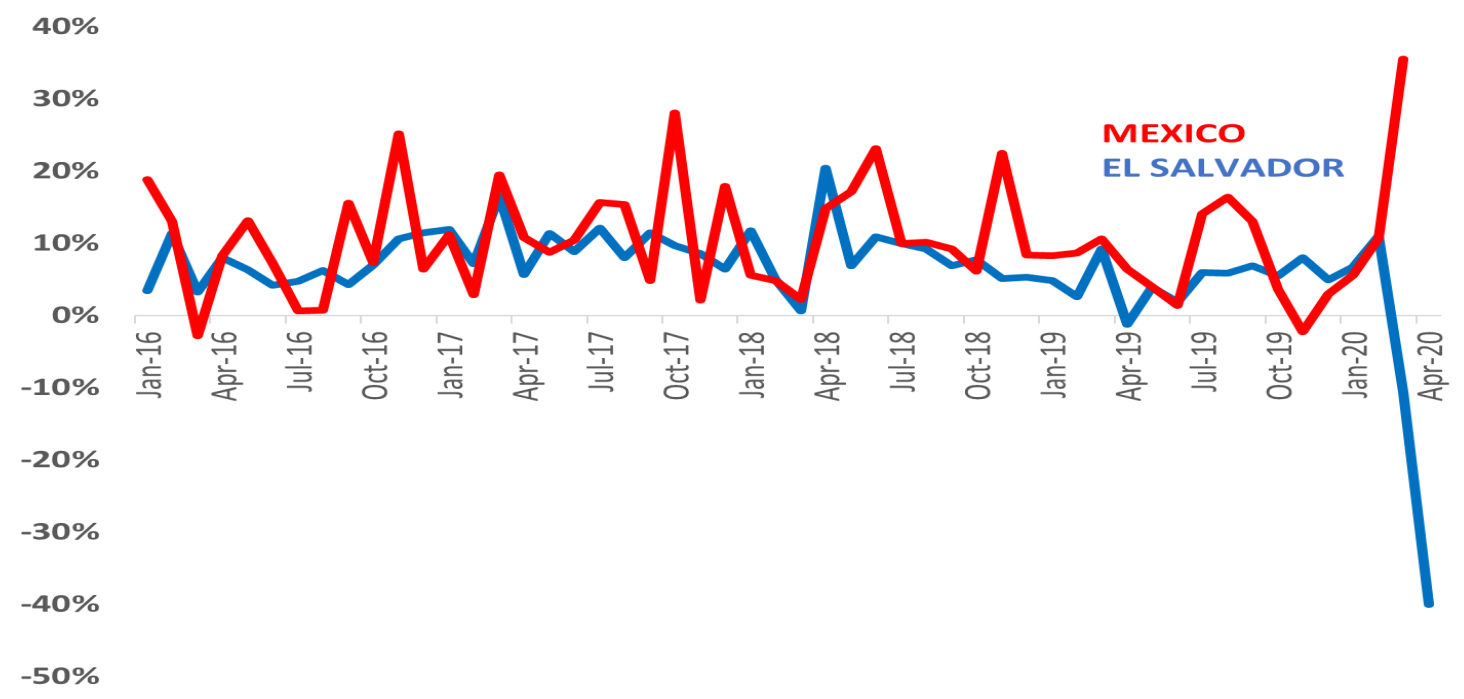

Note: Percentage growth in remittances from the United States is shown on a year-over-year basis. Remittances are denominated in U.S. dollars.

Source: Banco de México and Banco Central de Reserva de El Salvador

\footnotetext{
${ }^{10}$ See BBVA's report at https://www.bbvaresearch.com/en/publicaciones/remittances-to-mexico-could-fall-17-in2020-and-recover-between-2023-2028-due-to-covid-19/.
} 
While remittance flows are inherently volatile, the dramatic increase of remittances to Mexico during the second quarter - the highest increase ever recorded, amid a historical lockdown - was a remarkable development. In a striking contrast, El Salvador registered the sharpest drop in remittances ever witnessed (in line with an economic lockdown of historical proportions). The goal of this article is to address this question: How can we rationalize these two different outcomes in response to the pandemic?

\section{Potential Explanations and Conflicting Evidence}

Most practitioners and policy makers tend to relate this empirical conundrum to currency fluctuations. Specifically, the Mexican peso has undergone a sharp depreciation since the pandemic's onset (see figure 2). Intertemporal substitution might have played a role since a stronger dollar provide immigrants with additional incentives to send more resources back home. In recent crisis episodes, like the 1994 Mexican currency crisis and the 2008-09 global financial crisis, the exchange rate tends to overshoot its new equilibrium level as investors tend to seek refuge in the U.S. dollar. In principle, a stronger dollar in times of crisis may lead to more remittances with greater purchasing power back home.

\section{Figure 2: The Exchange Rate of the U.S. Dollar to the Mexican Peso}

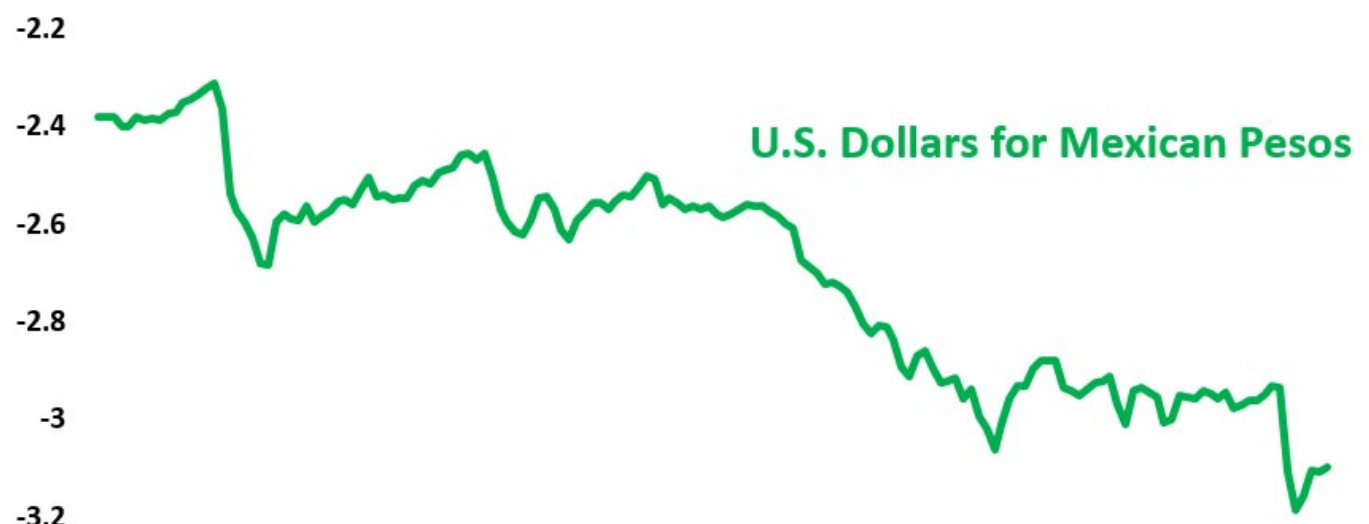

\section{$-3.2$}

$-3.4$

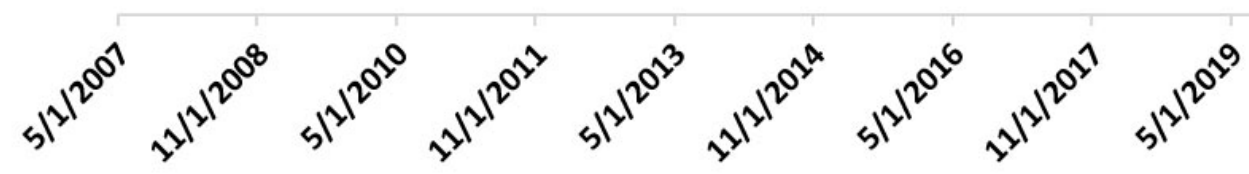

Note: MXN/USD nominal exchange rate expressed in natural logs.

Source: FRED economic data, Federal Reserve Bank of St. Louis 
Instead, because El Salvador's economy is fully dollarized, this substitution effect is absent. In sum, currency movements in Mexico that are absent in El Salvador may have contributed to the contrasting evidence in remittance inflows when the pandemic hit.

Although the simplicity of this explanation holds appeal, it is open to some challenge. Most notably, the contrasting experience during the 2008-09 global financial crisis provides a natural benchmark for comparison. During the COVID-19 crisis, the Mexican peso fell in value by 36 percent against the U.S. dollar, and during the 2008-09 global financial crisis the Mexican currency depreciated by 51 percent. However, in the previous crisis, remittances did not increase. Quite the opposite, in fact: they fell sharply, registering a 17 percent decline over the same period. Interestingly, this sudden drop in remittances was preceded by hefty growth rates during the housing boom of the early 2000 s.

In principle, it could be argued that the COVID-19 lockdown was a global phenomenon while the 2008-09 financial crisis was a U.S.-centered phenomenon. That is, if the United States enters a recession while Mexico's economy continues to expand, a decrease in remittances would be expected as immigrants typically use remittances to compensate for income differentials across household members located on both sides of the border. However, the Mexican economy contracted 5 percent in 2009, about as much as the U.S. economy. In sum, a sharp peso depreciation, combined with a severe recession in Mexico, resulted in much lower remittances during the previous crisis episode, very much in contrast with the current crisis. The question thus remains open: how can we rationalize the massive jump in remittances observed in March 2020? ${ }^{11}$

\section{An Alternative Hypothesis: Housing Starts and Remittances}

A blog post in the Atlanta Fed's macroblog correlated the flow of remittances to Mexico with the level of U.S. housing starts. ${ }^{12}$ During the housing boom and bust of the early 2000 s, changes in housing starts predicted remittances five months ahead with great accuracy. Similarly, the plunge in U.S. housing starts that began in 2006 was followed by a sizable drop in remittances five months later. This decline continued throughout the Great Recession of 2007-09.

\footnotetext{
${ }^{11}$ As of this writing, both Mexico and El Salvador are expected to report negative GDP growth rates in the second quarter of 2020, with forecasts showing that Mexico suffered a greater drop in year-over-year output. However, the difference in forecasts is only a few percentage points and thus not enough to account for the acute differences in remittances dynamics.

${ }^{12}$ See https://www.frbatlanta.org/blogs/macroblog/2009/05/28/housing-starts-remittances-and-macroeconomicdevelopments.aspx.
} 
These results should not be too surprising as the construction industry tends to rely heavily on immigrant labor. According to the Pew Research Center, undocumented immigrant workers alone account for 25 percent to 30 percent of the employment in most construction-related occupations. ${ }^{13}$ These numbers are likely to be conservative, with many registered contractors hiring hourly low-wage immigrant workers without keeping records. ${ }^{14}$ As expected, construction workers' income tends to be volatile, with more (less) resources being sent back home whenever these migrant workers experience a good (bad) spell of work in construction-related activities.

In this respect, the 2020 health crisis seems notably different than other U.S. output contractions. While the 2008-09 crisis was preceded by a sharp slowdown in construction that began in January 2006, the COVID-19 pandemic was preceded by a housing sector that had quickly gained strength in the summer of 2019, mostly as the result of lower mortgage interest rates. Figure 3 illustrates the strong momentum the housing sector carried into 2020 , and this momentum continued to drive activity in the first months of this year, taking only a brief respite in March. As remittances tend to react with some delay to developments in the housing industry, it could be argued that the surprising spike in remittances to Mexico seen in March-as the economy was shutting down-was the by-product of the rapid momentum in construction begun in 2019. In our view, is still too early to tell whether this hypothesis is valid. We are still in the early stages of this crisis, and future events, as more remittance data come to light, will test this conjecture.

Additional factors also deserve examination when attempting to explain the surge in remittances to Mexico. In what follows, we discuss factors that may warrant further consideration. First, industries such as agriculture, including meat and poultry, are big employers of immigrants. Clearly, these are jobs that were not negatively affected by the pandemic (if anything, these industries expanded over this period). Moreover, while restaurants stopped hosting patrons, there was a sizable increase in "food to go" alternatives. Rather than being employed as waiters and waitresses, immigrants typically found themselves working inside kitchens. Finally, households that were forced to remain indoors found

\footnotetext{
${ }^{13}$ Further details can be found at https://immigrationforum.org/article/immigrants-as-economic-contributorsthey-are-the-new-american-workforce/.

${ }^{14} \mathrm{~A}$ description of such practices can be found at https://drive.google.com/file/d/1Z9Lnutd3PAjuNaqPqLOMlvfMain4oFhT/view.
} 
a particular taste for home improvements and landscaping, ${ }^{15}$ sectors that are also disproportionately served by immigrants from these countries.

Figure 3. U.S. Housing Starts

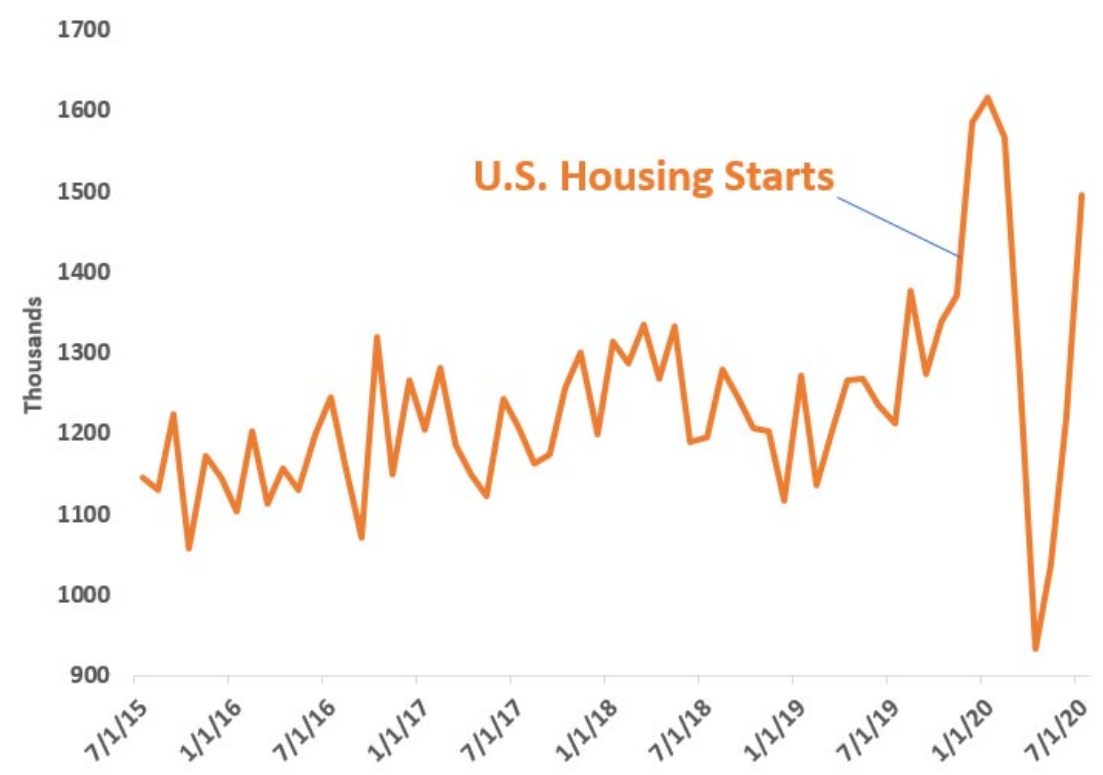

Note: Data indicate privately owned housing units.

Source: U.S. Census Bureau, FRED at St. Louis Fed

\section{The Case of El Salvador: Immigration Policy Uncertainty and Precautionary Savings}

We have so far challenged the popular narrative that remittances to Mexico increased because immigrants from this country took advantage of sizable fluctuations in the peso/dollar exchange rate. This explanation, however, would not apply to Salvadorans since their home economy is fully dollarized. So if the exchange rate is not a factor, and Mexican and Salvadoran immigrants have similar educational attainment, demographics, and employment characteristics, then our original question still stands: How can we explain such different results for remittances? We believe changes to U.S. immigration policies might help explain the differences.

Historically, immigration and remittances from El Salvador have been less responsive to the U.S. business cycle. The country's main immigration wave happened during the 1980s and early 1990s, when a long civil war forced many to flee their home and seek shelter in the United States. Since then, a big

\footnotetext{
${ }^{15}$ See, for example, https://www.wsj.com/articles/home-depot-covid-coronavirus-home-improvement-lockdownsstimulus-check-remodel-11597426959.
} 
share of the Salvadoran community has lived as refugees under a temporary protected status (TPS) that afforded them temporary U.S. residency. Steady family reunification followed thereafter.

Starting in 2018, changes to U.S. immigration policies have conditioned the continuity of the TPS program, currently set to expire in January 2021. Approximately 250,000 Salvadorans-about 20 percent of the total migrant population from this country-are thus subject to immediate removal from the United States if this program is discontinued. If the program is canceled, family members of those covered by TPS may also leave in order to preserve family unification. The uncertainty surrounding their immigration status, compounded by the income insecurity induced by the COVID-19 pandemic, exacerbated the negative outlook of these migrants, who may have responded by increasing their savings at the onset of the pandemic and thus sharply reducing the flow of remittances to their home country.

Finally, it is worth mentioning that those protected by TPS are legal immigrants who likely have more financial capacity and thus greater disposition to send money home. Facing an imminent crisis, the government of El Salvador implemented some emergency measures, which consisted of tax benefits for remittances' recipients and special agreements with MoneyGram and Western Union to offer temporarily commission-free money transfers during the pandemic. These policy incentives and the recent economic recovery led to an increase in these flows in recent months. While numbers remained negative in June, preliminary data for July indicate robust 10 percent growth on a year-over-year basis.

\section{Final Thoughts}

As the COVID-19 pandemic continues to afflict much of the global economy, the flow of remittances is likely to suffer substantially. Without adequate social protection mechanisms, this impeded flow could have severe effects on low-income countries, pushing households that traditionally receive these transfers into poverty and hunger while reducing economic activity and further compromising the national fiscal stance. Acknowledging these general patterns, this article highlights some important heterogeneity among remitters that can lead to country-specific effects. More postpandemic data are needed to validate some of our proposed hypotheses. 


\section{Recommended Reading}

Acosta, P. 2006. Labor supply, school attendance, and remittances from international migration: The case of El Salvador. World Bank Policy Research Working Paper 3903.

Acosta, P., E. Lartey, and F. Mandelman. 2009. Remittances and the Dutch disease. Federal Reserve Bank of Atlanta Working Paper 2007-8.

Amuedo-Dorantes, C., and S. Pozo. 2004. Workers' remittances and the real exchange rate: A paradox of gifts. World Development 32, 1407-17.

Chami, R., T. Cosimano, and M. Gapen. 2006. Beware of emigrants bearing gifts: Optimal fiscal and monetary policy in the presence of remittances. International Monetary Fund Working Paper $06 / 61$.

Durdu, B., and S. Sayan. 2008. Emerging market business cycles with remittance fluctuations. Federal Reserve Board International Finance Discussion Paper 2008-946.

Fajnzylber, P., and H. López. 2008. Remittances and development: Lessons from Latin America. World Bank, Washington, DC.

Funkhouser, E. 1992. Migration from Nicaragua: Some recent evidence. World Development 20, 1209-18.

Giuliano, P., and M. Ruiz-Arranz. 2006. Remittances, financial development and growth. IZA Discussion Paper Series no. 2160.

Hanson, G. 2007. Emigration, remittances, and labor force participation in Mexico. Integration and Trade Journal 27, 73-103.

Lartey, E., F. Mandelman, and P. Acosta. 2008. Remittances, exchange rate regimes and the Dutch disease: A panel data analysis. Federal Reserve Bank of Atlanta Working Paper 2008-12.

Litterman, R. 1986. Forecasting with Bayesian vector autoregressions: Five years of experience. Journal of Business and Economic Statistics 4, 25-30.

Loser, C., C. Lockwood, A. Minston, and L. Balcazar. 2006. The macro-economic impact of remittances in Latin America: Dutch disease or Latin cure? Unpublished manuscript, Inter-American Dialogue, Washington, DC.

Lucas, R., and O. Stark. 1985. Motivations to remit: Evidence from Botswana. Journal of Political Economy 93, 901-18.

Mandelman, Federico, and Andrei Zlate. 2019. Immigration, remittances and business cycles. Journal of Monetary Economics 59(2), 196-213.

Mendoza, E. 1991. Real business cycles in small open economies. American Economic Review 81, 797-818.

World Bank. 2008. Migration and Remittances Factbook 2008. World Bank, Washington, DC.

Yang, D., and H. Choi. 2007. Are remittances insurance? Evidence from rainfall shocks in the Philippines. World Bank Economic Review 21, 219-48.

Yang, D. 2008. International migration, remittances, and household investment: Evidence from Philippine migrants' exchange rate shocks. Economic Journal 118, 591-630. 